\title{
Tryonia, a new taenitidoid fern genus segregated from Jamesonia and Eriosorus (Pteridaceae)
}

\author{
Alyssa T. Cochran', Jefferson Prado², Eric Schuettpelz ${ }^{1,3}$ \\ I Department of Biology and Marine Biology, University of North Carolina Wilmington, 601 South College \\ Road, Wilmington, NC 28403-5915, U.S.A. 2 Instituto de Botânica, C.P. 68041, 04045-972, São Paulo, SP, \\ Brazil 3 Department of Botany (MRC 166), National Museum of Natural History, Smithsonian Institution, \\ PO Box 37012, Washington DC 20013-7012, U.S.A.
}

Corresponding author: Eric Schuettpelz (schuettpelze@si.edu)

Academic editor: L. Penev | Received 20 December 2013 | Accepted 19 February 2014 | Published 26 February 2014

Citation: Cochran AT, Prado J, Schuettpelz E (2014) Tryonia, a new taenitidoid fern genus segregated from Jamesonia and Eriosorus (Pteridaceae). PhytoKeys 35: 23-43. doi: 10.3897/phytokeys.35.6886

\begin{abstract}
The Neotropical fern genera Eriosorus and Jamesonia have long been thought of as close relatives. Molecular phylogenetic studies have confirmed this notion but have also revealed that neither genus is monophyletic with respect to the other. As a result, all known species of Eriosorus were recently subsumed under the older generic name Jamesonia. Here, through an analysis of a four-gene plastid dataset, we show that several species traditionally treated in Eriosorus are in fact more closely related to other taenitidoid fern genera (namely Austrogramme, Pterozonium, Syngramma, and Taenitis) than they are to the large Jamesonia sensu lato clade. Tryonia Schuettp., J.Prado \& A.T.Cochran gen. nov. is described to accommodate these species and four new combinations are provided. Tryonia is confined to southeastern Brazil and adjacent Uruguay; it is distinct (from most species of Jamesonia) in having stramineous rachises.
\end{abstract}

\section{Keywords}

Brazil, phylogeny, pteridophytes, Taenitidoideae, taxonomy

\section{Introduction}

The Neotropical genus Jamesonia Hook. \& Grev. sensu stricto is among the most distinctive of all fern genera. It has linear, indeterminate leaves bearing highly reduced, coriaceous pinnae covered with dense pubescence (Tryon 1962; Fig. 1). These morphological characteristics are generally considered to be an adaptation to the high-

Copyright Alyssa T. Cochran et al. This is an open access article distributed under the terms of the Creative Commons Attribution License (CC BY 4.0), which permits unrestricted use, distribution, and reproduction in any medium, provided the original author and source are credited. 


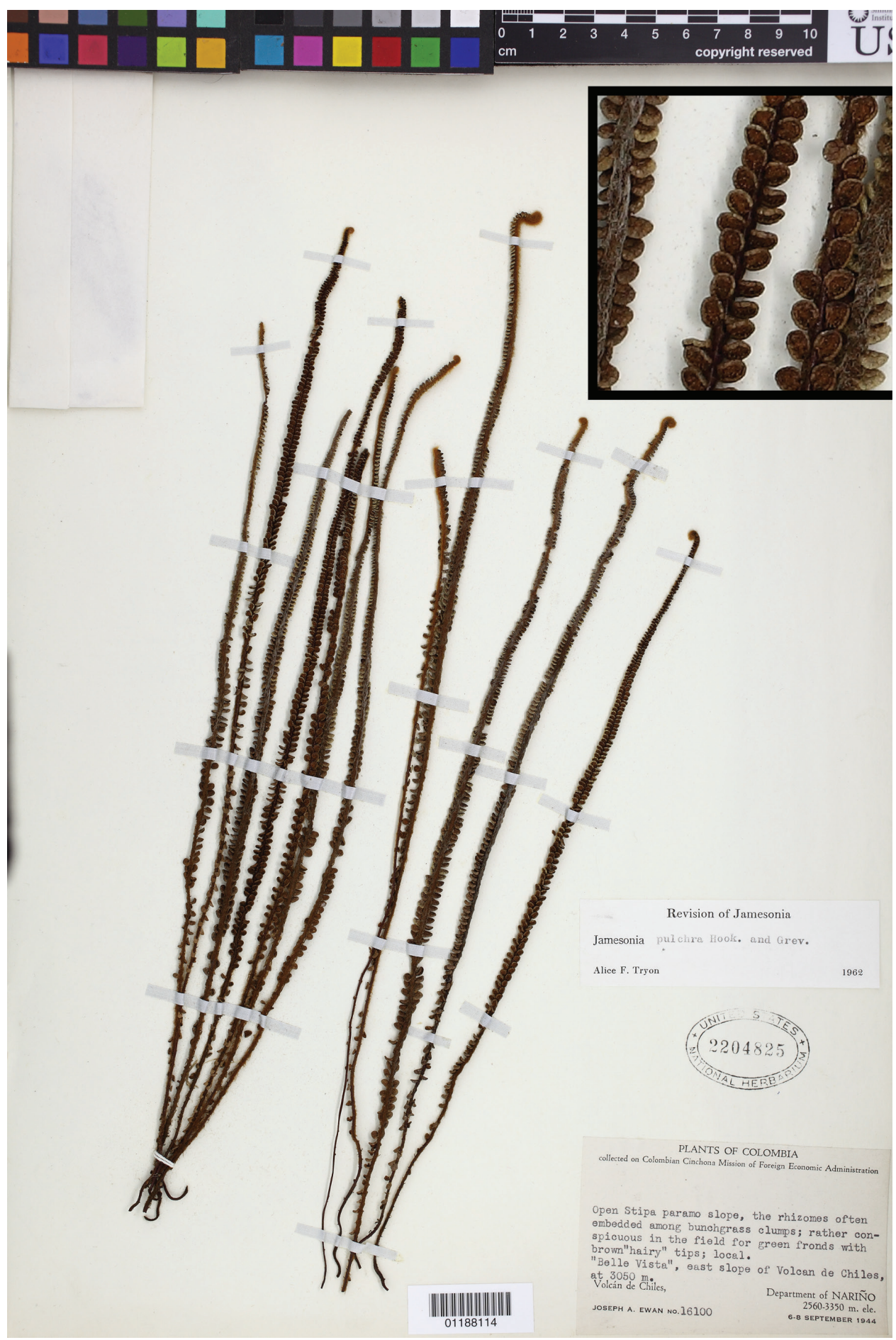

Figure I. Jamesonia pulchra Hook. \& Grev., the type species of Jamesonia. Ewan 16100 (US), inset detail of (castaneous) rachis magnified $4 \times$. 
elevation Andean páramo habitats where most Jamesonia species reside (Tryon et al. 1990). Based on reproductive and other cryptic morphological characteristics, Jamesonia has long been thought to be closely related to the genus Eriosorus Fée (Tryon 1962, 1970, Tryon and Tryon 1982). Eriosorus mostly occupies middle-elevation habitats in the Andes and its leaves are much more typical of ferns, usually being very dissected and rather delicate in texture (Tryon 1970; Figs 2, 3). Recent analyses have demonstrated that Jamesonia is both nested within Eriosorus and polyphyletic (Prado et al. 2007, Sánchez-Baracaldo 2004a, 2004b, Schneider et al. 2013, Schuettpelz et al. 2007), supporting the hypothesis of Tryon $(1962,1970)$ that the unique morphology of Jamesonia evolved independently multiple times. This finding prompted the recent recombination of all known species of Eriosorus into Jamesonia (sensu lato, Christenhusz et al. 2011).

Although it is clear that species of Jamesonia sensu stricto are intermixed with those previously assigned to Eriosorus, relationships remain rather poorly supported and additional studies are needed to better resolve the evolutionary history of this group. With that said, the isolated phylogenetic position revealed for one Brazilian species requires special attention. In the most comprehensive study of Jamesonia sensu lato to date (Sánchez-Baracaldo 2004b), two accessions of E. myriophyllus (Sw.) Copel. (Fig. 4) were resolved together and well supported as sister to the remainder of Jamesonia sensu lato. However, it is clear from the phylogram included in the Sánchez-Baracaldo (2004b) study that these accessions are genetically more similar to the outgroup used than they are to the remainder of the ingroup, suggesting that the phylogenetic position of E. myriophyllus may be an artifact of including a single outgroup genus (Pterozonium Fée). Subsequent analyses with a broader phylogenetic context but including fewer exemplars from within Jamesonia sensu lato, actually found E. myriophyllus to be most closely related to the genus Taenitis Willd. ex Schkuhr (Prado et al. 2007, Schneider et al. 2013).

Here, through analyses of a four-gene ( $a t p A, c h l L, r b c L$, and $r p s 4$ ) plastid dataset that incorporates many Eriosorus and Jamesonia sensu stricto species, as well as a broad sampling of related genera, we aim to better resolve the phylogenetic position of $E$. myriophyllus and allied species. Based on our results, we describe a new genus, Tryonia Schuettp., J.Prado \& A.T.Cochran, to accommodate this species and its closest allies.

\section{Methods}

\section{Sampling}

A total of thirty-eight collections were sampled for the phylogenetic analysis, including four individuals of Eriosorus myriophyllus, nine other species of Eriosorus, eight Jamesonia sensu stricto species, and seventeen additional species representing other genera in the taenitidoid clade (Prado et al. 2007, Sánchez-Baracaldo 2004a, Schuettpelz et al. 2007, Table 1). 


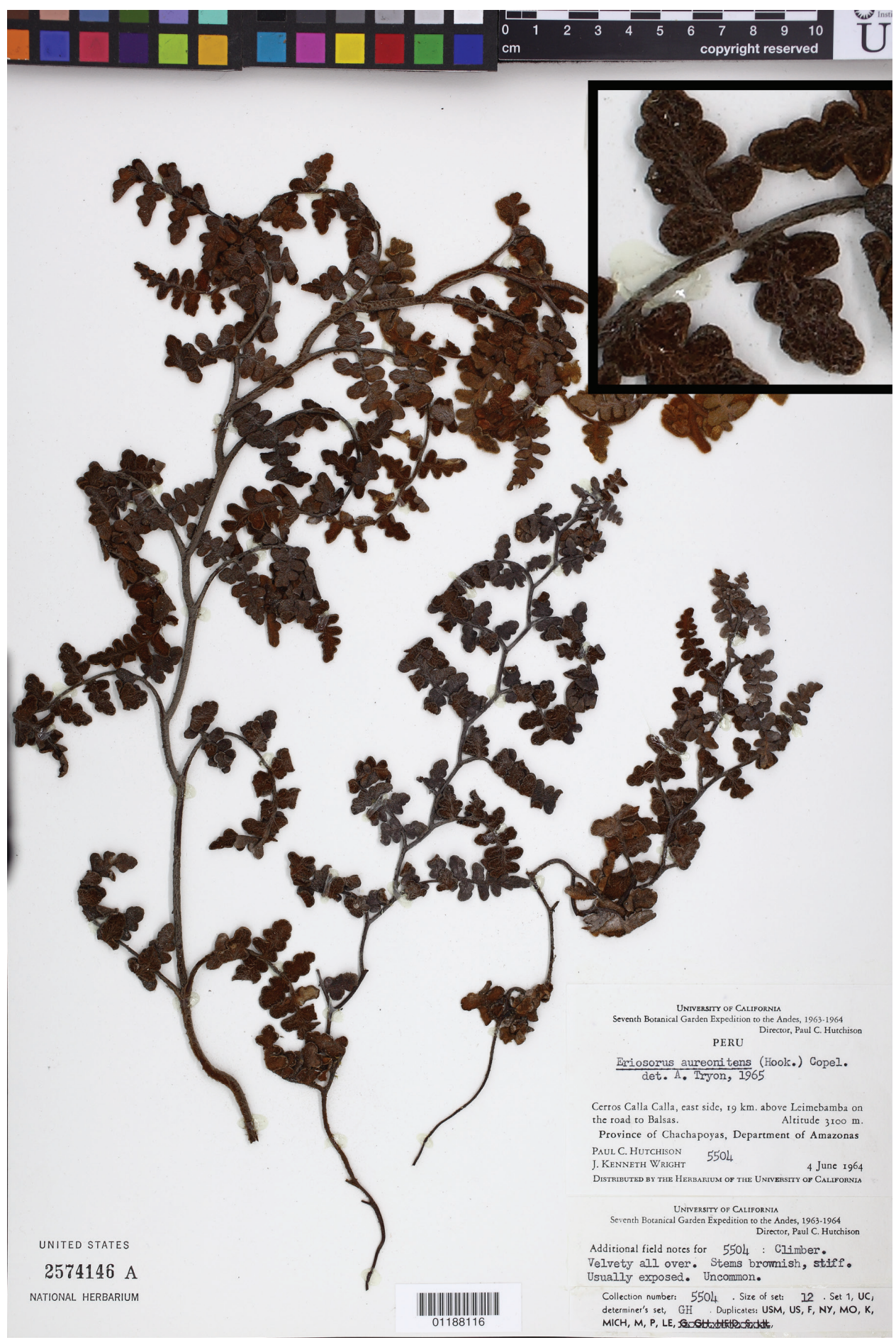

Figure 2. Jamesonia aureonitens (Hook.) Christenh., the type species of Eriosorus. Hutchison 5504 (US), inset detail of (castaneous) rachis magnified $4 x$. 


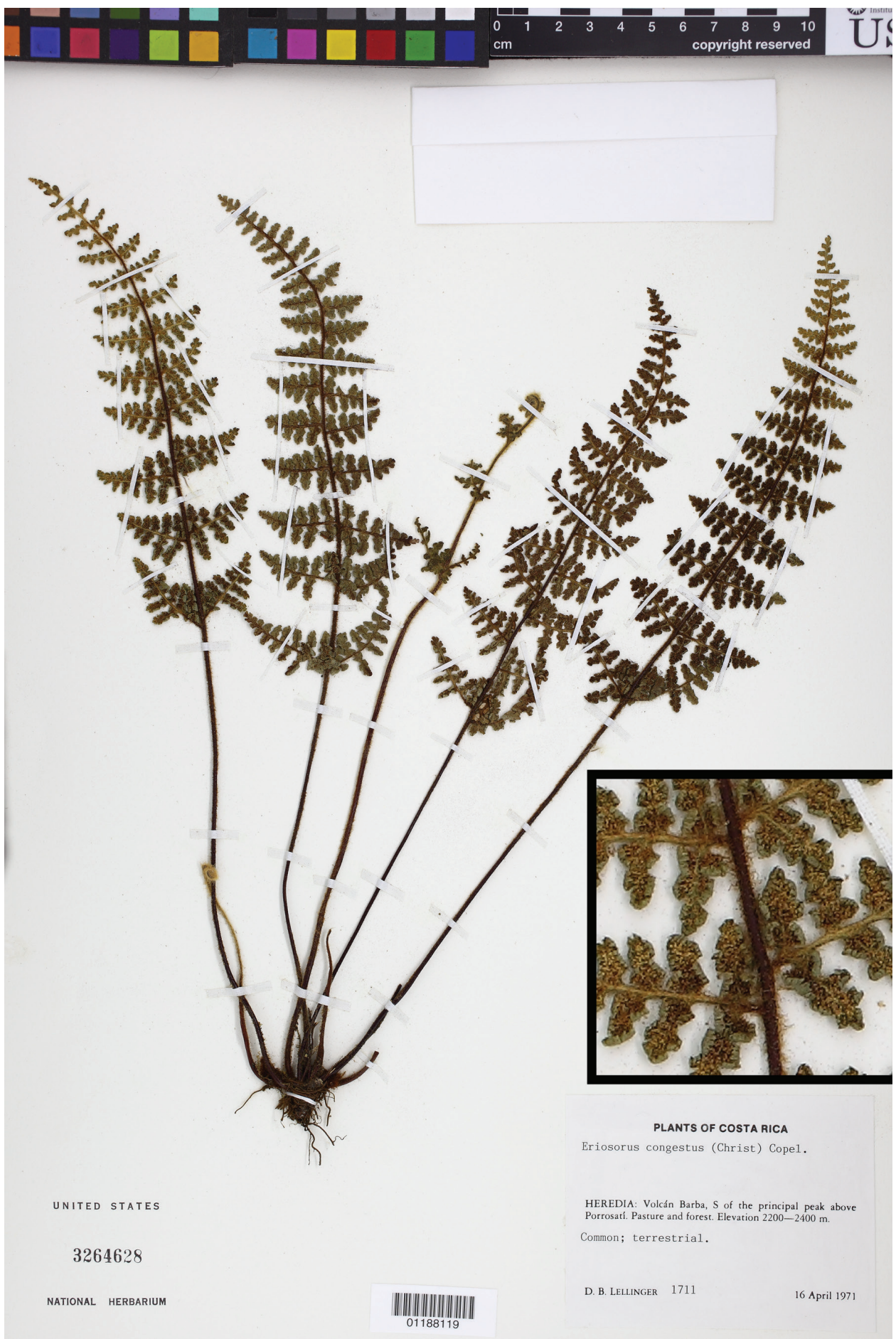

Figure 3. Jamesonia congesta (Christ) Christenh., a species with generalized morphology (Tryon 1970) previously classified in Eriosorus. Lellinger 1711 (US), inset detail of (castaneous) rachis magnified 4x. 


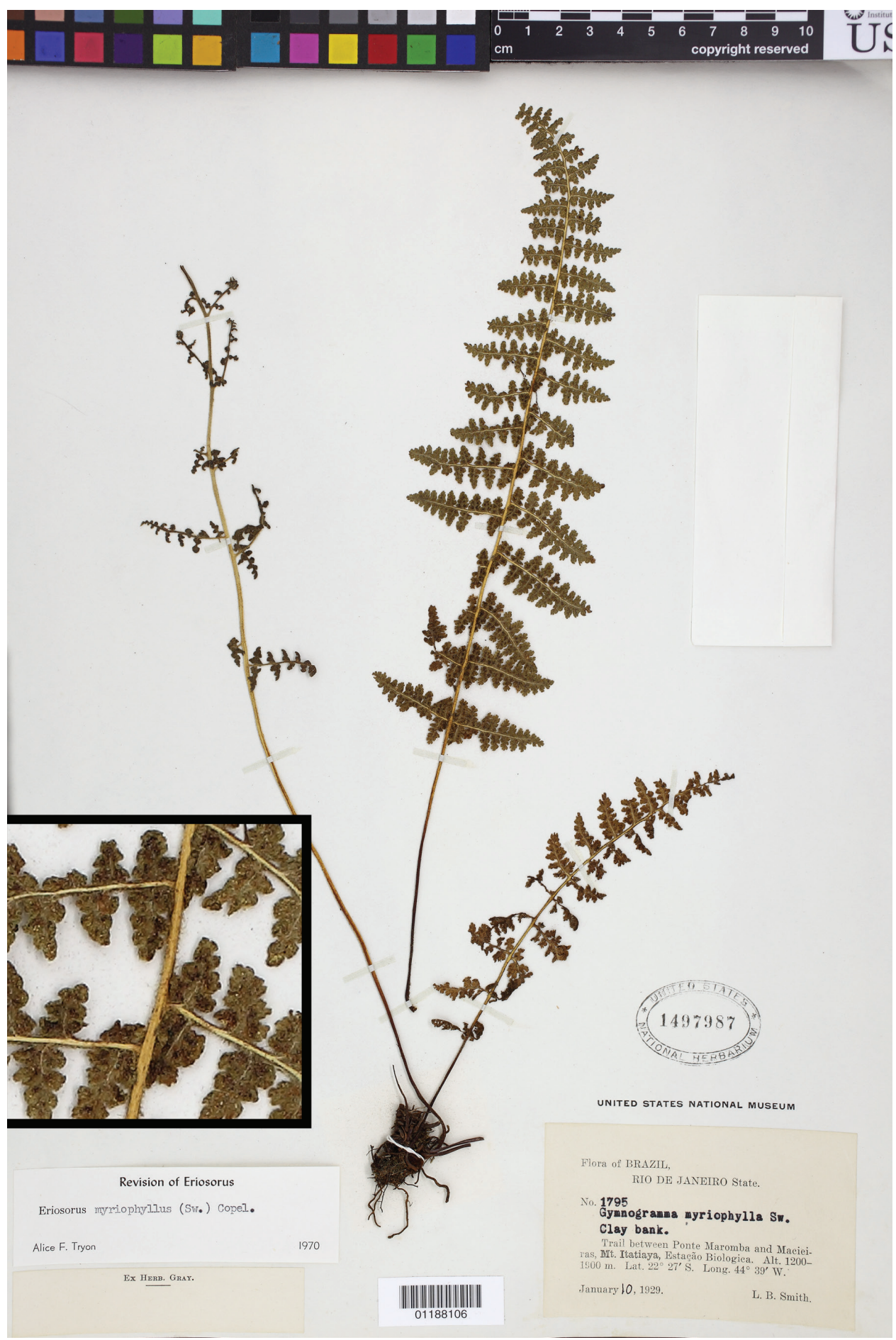

Figure 4. Tryonia myriophylla (Sw.) Schuettp., J.Prado \& A.T.Cochran, the type species of Tryonia. Smith 1795 (US), inset detail of (stramineous) rachis magnified 4x. 
Table I. Collections included in our phylogenetic analyses supporting the recognition of Tryonia, with voucher information and corresponding GenBank accession numbers.

\begin{tabular}{|c|c|c|c|c|c|c|}
\hline Species & Voucher & $\operatorname{atp} A$ & chlL & $r b c L$ & $r p s 4$ & FLDB $^{\dagger}$ \\
\hline Actiniopteris dimorpha $\mathrm{P}$ & hneider s.n. (GOET) & F452066 & KJ416295 & F452130 & $\mathrm{J} 416352$ & 3515 \\
\hline Actiniotteris semiflabellata Pic Serm & Smith s.n. (UC) & $\mathrm{J} 416270$ & KJ416296 & $\mathrm{kJ} 416326$ & $\mathrm{~J} 416353$ & 742 \\
\hline Anogramma $\mathrm{l}$ & (D) & 416271 & KJ416297 & KJ416327 & 6354 & 4822 \\
\hline $\begin{array}{r}\text { Austrogramm } \\
\mathrm{Her}\end{array}$ & (C & NA & NA & NA & 1702 & NA \\
\hline $\begin{array}{r}\text { Austrogramme } \\
\text { E.F }\end{array}$ & Hode & NA & NA & NA & 7704 & NA \\
\hline Cosentinia vellea & 资 & KJ416272 & KJ416298 & KJ416328 & KJ416355 & 8670 \\
\hline & ) & $\mathrm{J} 416273$ & KJ416299 & KJ416329 & KJ416356 & 5587 \\
\hline$i a b l$ & (I & $J 416274$ & KJ416300 & EF452154 & KJ 416357 & 2437 \\
\hline Jamesoni & huettr & 75 & 01 & 30 & 58 & 379 \\
\hline $\begin{array}{r}\text { Jamesonia che } \\
\mathrm{Chr}\end{array}$ & Е) & 76 & KJ416302 & 31 & 59 & 7694 \\
\hline $\begin{array}{r}\text { Jamesonia } \\
\mathrm{Cl}\end{array}$ & cusz & J416277 & KJ416303 & KJ416332 & $\mathrm{KJ} 4$ & 5272 \\
\hline $\begin{array}{r}\text { Jamesonia elongat } \\
\mathrm{J} . S\end{array}$ & thfel & KJ416278 & KJ416304 & KJ41 & $\mathrm{KJ} 4$ & 7362 \\
\hline $\begin{array}{r}\text { Jamesonia fle } \\
\text { Chri }\end{array}$ & ( & KJ416279 & KJ416305 & KJ416334 & KJ416362 & 5273 \\
\hline Jamesonia goudoti & UKE) & 416280 & KJ416306 & KJ416335 & 63 & 7414 \\
\hline Jamesonia h & E) & KJ 416281 & KJ416307 & KJ416336 & 64 & 7397 \\
\hline Jamesonia in & & IA & NA & NA & 08 & $\mathrm{NA}$ \\
\hline (2) & ( & NA & NA & NA & F321746 & NA \\
\hline Jamesonia & Sundue 1 & 6282 & 308 & 337 & 65 & 6049 \\
\hline Jamesonia scamr & & J416283 & KJ416309 & KJ416338 & KJ416366 & 588 \\
\hline Jamesonit & & 84 & 310 & 339 & 67 & 386 \\
\hline Jamesonia u & rusz $08-0$ & KJ416285 & KJ416311 & KJ416340 & KJ416368 & 5275 \\
\hline Onychium jaf & hneider s & EF452107 & KJ416312 & KJ416341 & NA & 3463 \\
\hline mychium lucidum (D.Don) & 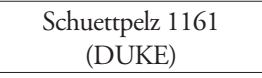 & $\mathrm{J} 416286$ & KJ416313 & KJ416342 & NA & 4904 \\
\hline $\begin{array}{r}\text { Pityrogramme } \\
\mathrm{D} \\
\end{array}$ & $\mathrm{S}$ & F452112 & KJ416314 & EF452166 & KJ416369 & 2561 \\
\hline $\begin{array}{r}\text { Pityrogramma c } \\
\mathrm{D}\end{array}$ & Prado 217 20 & KJ416287 & KJ416315 & KJ416343 & KJ416370 & 8755 \\
\hline $\begin{array}{r}\text { Pityrogramma } \\
\mathrm{D}\end{array}$ & Moran & EF463857 & KJ416316 & EF452167 & KJ416371 & 3769 \\
\hline $\begin{array}{r}\text { Pterozonium br } \\
\text { Lel }\end{array}$ & 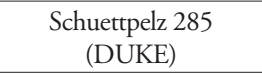 & 52124 & KJ416317 & EF452175 & KJ416372 & 2453 \\
\hline Pterozonium c & & & & & 03 & NA \\
\hline Pterozonium rer & & & $N$ & & AF321704 & NA \\
\hline Syngn & & & & & 701 & NA \\
\hline Taenitis blechnoides (Willd.) Sw. & Sch & 88 & 18 & 44 & 73 & 4102 \\
\hline 然 & $\begin{array}{l}\text { Schuettp } \\
\text { (DU }\end{array}$ & 6289 & KJ416319 & KJ416345 & KJ416374 & 4270 \\
\hline
\end{tabular}




\begin{tabular}{|c|c|c|c|c|c|c|}
\hline $\begin{array}{l}\text { Tryonia areniticola (Schwartsb. } \\
\text { \& Labiak) Schuettp., J.Prado \& } \\
\text { A.T.Cochran }\end{array}$ & Prado 2169 (SP) & NA & KJ416320 & KJ416346 & KJ416375 & 8433 \\
\hline $\begin{array}{c}\text { Tryonia myriophylla (Sw.) Schuettp., } \\
\text { J.Prado \& A.T.Cochran }\end{array}$ & Schuettpelz 1411 (SP) & KJ 416290 & KJ416321 & KJ 416347 & KJ 416376 & 8345 \\
\hline $\begin{array}{c}\text { Tryonia myriophylla (Sw.) Schuettp., } \\
\text { J.Prado \& A.T.Cochran }\end{array}$ & Schuettpelz 1449 (SP) & KJ 416291 & KJ416322 & KJ 416348 & KJ 416377 & 8384 \\
\hline $\begin{array}{c}\text { Tryonia myriophylla (Sw.) Schuettp., } \\
\text { J.Prado \& A.T.Cochran }\end{array}$ & Schuettpelz 1461 (SP) & KJ 416292 & KJ416323 & KJ 416349 & KJ 416378 & 8396 \\
\hline $\begin{array}{c}\text { Tryonia myriophylla (Sw.) Schuettp., } \\
\text { J.Prado \& A.T.Cochran }\end{array}$ & Prado 2186 (SP) & KJ 416293 & KJ416324 & KJ416350 & $\mathrm{NA}$ & 8753 \\
\hline $\begin{array}{c}\text { Tryonia schwackeana (Christ) } \\
\text { Schuettp., J.Prado \& A.T.Cochran }\end{array}$ & Schuettpelz 1433 (SP) & KJ416294 & KJ416325 & KJ416351 & KJ416379 & 8367 \\
\hline
\end{tabular}

${ }^{\dagger}$ Fern Lab Database voucher number (see http://fernlab.biology.duke.edu for additional information concerning these collections)

\section{DNA extraction, amplification, and sequencing}

Genomic DNA was typically extracted using a modified CTAB protocol (Doyle and Doyle 1987), as described in detail in Beck et al. (2011). Four plastid gene regions (atpA, chlL, $r b c L$, and $r p s 4$ ) were amplified using the polymerase chain reaction (PCR). Each reaction incorporated $13.6 \mu \mathrm{l}$ ultrapure water, $2 \mu \mathrm{l}$ buffer (10x), $2 \mu \mathrm{l}$ dNTPs (2 $\mathrm{mM}$ each), $0.2 \mu$ l Choice-Taq DNA Polymerase (5 units/ $\mu$, Denville Scientific), 0.2 $\mu \mathrm{l}$ BSA $(10 \mathrm{mg} / \mathrm{ml}), 1 \mu \mathrm{l}$ forward primer $(10 \mu \mathrm{M}), 1 \mu \mathrm{l}$ reverse primer $(10 \mu \mathrm{M})$, and $1 \mu \mathrm{l}$ template DNA (primer details are provided for each gene in Table 2). All thermal cycling protocols employed an initial denaturation step $\left(95^{\circ} \mathrm{C}\right.$ for $\left.2 \mathrm{~min}\right), 35 \mathrm{ampli}-$ fication cycles, and a final elongation step $\left(71^{\circ} \mathrm{C}\right.$ for $\left.5 \mathrm{~min}\right)$. Each amplification cycle involved a denaturation step $\left(95^{\circ} \mathrm{C}\right.$ for $\left.0.5 \mathrm{~min}\right)$, an annealing step $\left(50{ }^{\circ} \mathrm{C}\right.$ for $0.5 \mathrm{~min}$ for atp $A$, chlL, and $r p s 4 ; 45^{\circ} \mathrm{C}$ for $0.5 \mathrm{~min}$ for $\left.r b c L\right)$, and an elongation step $\left(71^{\circ} \mathrm{C}\right.$ for $1 \mathrm{~min}$ for atpA and $c h l L ; 71^{\circ} \mathrm{C}$ for 1.5 min for $r p s 4$ and $\left.r b c L\right)$.

Amplifications were visualized using standard gel electrophoresis and imaging approaches. Unincorporated nucleotides and primers were removed from successful reactions by adding $1.0 \mu \mathrm{l}$ Shrimp Alkaline Phosphatase ( $1 \mathrm{unit} / \mu \mathrm{l})$ and $0.5 \mu \mathrm{l}$ Exonuclease I (10 units/ $\mu \mathrm{l})$ to each reaction and incubating at $37^{\circ} \mathrm{C}$ for $15 \mathrm{~min}$. Reactions were then heated to $80^{\circ} \mathrm{C}$ for $15 \mathrm{~min}$ to inactivate the enzymes.

Sequencing reactions were carried out, in both directions, with the amplification primers, following a standard protocol (Schuettpelz and Pryer 2007). For $r b c L$, two additional (internal) sequencing primers were utilized (Table 2). Sequencing reactions were cleaned using the ZR-96 DNA Sequencing Clean-up Kit (Zymo Research), according to the manufacturer's protocol. Sealed plates were submitted to Operon (Huntsville, Alabama) for sequencing.

Sequencing reads were independently (for each PCR product) assembled and edited using Sequencher (Gene Codes Corporation). The 110 new consensus sequences were added to the Fern Lab Database (http://fernlab.biology.duke.edu) and deposited into GenBank (Table 1). For four (of thirty-eight) collections, we could only obtain three of the four gene regions targeted (Table 1). For six collections, an atp $A$ and/or 
Table 2. Primers utilized in this study supporting the recognition of Tryonia.

\begin{tabular}{c|c|c|c|c}
\hline Region & Name & Type & Sequence & Reference \\
\hline$a t p A$ & atpA-F1 & Forward & GAATCTGATAATGTTGGGGCTG & This study \\
\hline$a t p A$ & atpA-R1 & Reverse & AAACATCTCCNGGATAYGCTTC & This study \\
\hline$c h l L$ & chlL-F1 & Forward & GRATTGGMAARTCAACAACTAGCTG & This study \\
\hline$c h l L$ & chlL-R1 & Reverse & CBAGTACRGGCATGGGRCAAGCTTC & This study \\
\hline$r b c L$ & ES-rbcL-1F & Forward & ATGTCACCACAAACGGAGACTAAAGC & Schuettpelz and Pryer 2007 \\
\hline$r b c L$ & ES-rbcL-1361R & Reverse & TCAGGACTCCACTTACTAGCTTCACG & Schuettpelz and Pryer 2007 \\
\hline$r b c L$ & ES-rbcL-628F & Forward & CCATTYATGCGTTGGAGAGATCG & Schuettpelz and Pryer 2007 \\
\hline$r b c L$ & ES-rbcL-654R & Reverse & GAARCGATCTCTCCAACGCAT & Schuettpelz and Pryer 2007 \\
\hline$r p s 4$ & rps5 & Forward & ATGTCCCGTTATCGAGGACCT & Souza-Chies et al. 1997 \\
\hline$r p s 4$ & trnS & Reverse & TACCGAGGGTTCGAATC & Souza-Chies et al. 1997 \\
\hline
\end{tabular}

${ }^{\dagger}$ Primer used only for sequencing.

$r b c L$ sequence had already been published; these existing sequences (from Schuettpelz and Pryer 2007 and Schuettpelz et al. 2007) were obtained directly from GenBank, as were seven rps4 sequences (from Sánchez-Baracaldo 2004a, 2004b) corresponding to species not otherwise available to us (Table 1). All new and existing sequences were aligned, by gene region, using Mesquite (Maddison and Maddison 2011). The final atp $A$, chlL, rbcL, and rps 4 datasets included 30, 31, 31, and 35 taxa, respectively (see Table 3 for additional details concerning our alignments).

Table 3. Details for the alignments analyzed in this study supporting the recognition of Tryonia.

\begin{tabular}{c|c|c|c|c|c|c}
\hline & & \multicolumn{3}{|c|}{ Characters } & Data & Bipartitions \\
\hline Dataset & Taxa & Total & Included & Variable & Missing $^{\dagger}$ & Supported $^{\ddagger}$ \\
\hline atp $A$ & 30 & 1506 & 629 & 113 & $1.04 \%$ & 11 \\
\hline$c h l L$ & 31 & 523 & 523 & 120 & $0.92 \%$ & 15 \\
\hline$r b c L$ & 31 & 1309 & 1309 & 250 & $0.39 \%$ & 15 \\
\hline rps4 & 35 & 1176 & 560 & 177 & $1.77 \%$ & 17 \\
\hline Combined & 38 & 4514 & 3021 & 660 & $17.76 \%$ & 25 \\
\hline
\end{tabular}

${ }^{\dagger}$ Calculation based on included characters

${ }^{\ddagger}$ Bayesian posterior probability $\geq 0.95$

\section{Phylogenetic analyses}

Bayesian phylogenetic analyses were conducted independently for each of the four single-gene datasets using MRBAYES version 3.2.1 (Huelsenbeck and Ronquist 2001, Ronquist and Huelsenbeck 2003). These Bayesian analyses utilized the GTR+C+I model of sequence evolution (the most complex model available) and consisted of four independent runs per dataset, each utilizing four chains and proceeding for five million generations, with trees sampled every 4000 generations. After completion of each analysis, we examined the standard deviation of split frequencies among the runs, plot- 
ted the output parameter estimates using Tracer 1.5 (Rambaut and Drummond 2009), and very conservatively excluded the first 250 trees (one million generations) from each run. A majority-rule consensus phylogeny with clade posterior probabilities was then calculated from the remaining 4000 trees, for each gene. Based on earlier studies with broader sampling (Prado et al. 2007, Sánchez-Baracaldo 2004a), we rooted our resulting gene trees with Actiniopteris and Onychium.

We compared the results of our single-gene analyses, looking for conflicts that were supported by a Bayesian posterior probability $\geq 0.95$. Finding none, we concatenated the four datasets. The resulting 38-taxon combined dataset was analyzed as above, but with model parameters estimated and optimized separately for each gene and each run proceeding for 20 million generations. We sampled trees every 16,000 generations and excluded the first four million generations from each run prior to calculating a majority-rule consensus phylogeny with clade posterior probabilities.

\section{Results}

The four single-gene ( $a t p A, c h l L, r b c L$, and $r p s 4$ ) datasets contained varying amounts of phylogenetic signal, providing significant support (Bayesian posterior probability, BPP $\geq 0.95$ ) for as few as 11 and as many as 17 bipartitions (Table 3 ). The single-gene trees were largely consistent in their resolved relationships (trees not shown) and there were no well-supported (BPP $\geq 0.95)$ conflicts among them.

Our combined four-gene dataset comprised a total of 4514 characters, of which 660 were variable (Table 3). Analysis of this dataset resulted in a phylogeny with considerably improved support relative to the single-gene phylogenies; 25 bipartitions had a BPP $\geq 0.95$ (Fig. 5). The separation of Actiniopteris and Onychium from the remaining taenitidoid genera was well supported $(\mathrm{BPP}=1.00)$. Anogramma, Cosentinia, and Pityrogramma formed a well-supported clade that was, in turn, well-supported as sister to a robust clade including Austrogramme, Pterozonium, Syngramma, Taenitis, and all sampled species previously assigned to either Jamesonia or Eriosorus (Fig. 5).

The vast majority of our Jamesonia sensu lato collections come together in a clade on a rather long branch; within this clade branches are short and support is frequently lacking. Six samples previously included within Jamesonia sensu lato are not allied to that larger clade, but rather are embedded within a well-supported clade that also contains Austrogramme, Pterozonium, Syngramma, and Taenitis (Fig. 5).

\section{Discussion}

Most species previously assigned to Eriosorus and Jamesonia sensu stricto have been consistently resolved together in a well-supported clade (Prado et al. 2007, SánchezBaracaldo 2004a, 2004b, Schneider et al. 2013, Schuettpelz et al. 2007). And, although support for relationships within this large clade has been generally lacking, the 


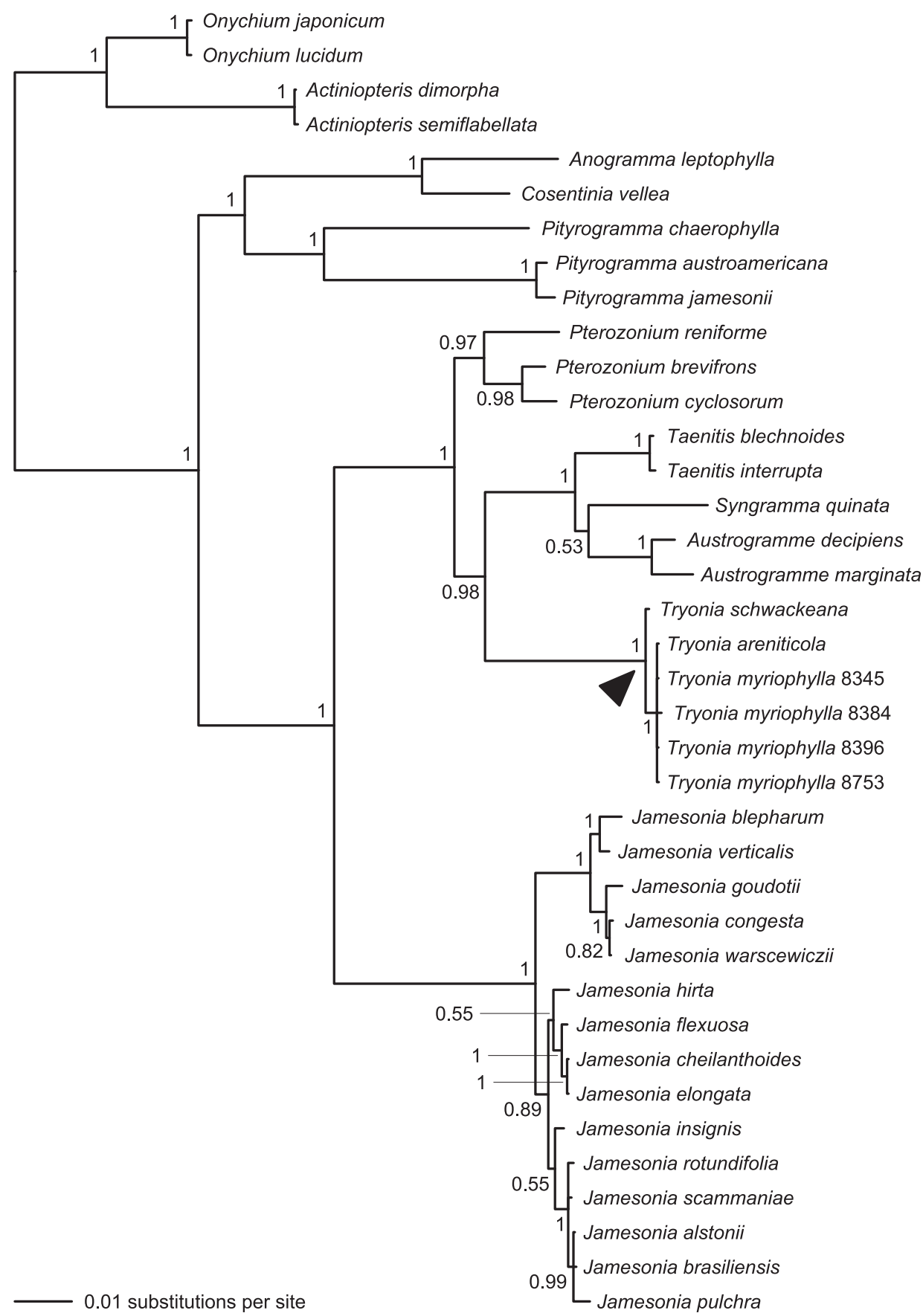

Figure 5. Phylogeny resulting from Bayesian analysis of our combined four-gene (atpA, $\operatorname{chlL}, r b c L$, and $r p s 4)$ plastid dataset. Posterior probabilities $(\geq 0.50)$ are provided at the nodes. Note that species now treated in Tryonia (black arrowhead) are distinct from Jamesonia, the genus in which these species were most recently placed. Numbers provided for Tryonia myriophylla samples are Fern Lab Database voucher numbers (Table 1). 
hypothesis that Jamesonia sensu stricto was derived from within Eriosorus (Tryon 1962, 1970) has received considerable backing. In our combined analysis, we too find strong support for a clade containing most sampled Eriosorus and Jamesonia sensu stricto species (Fig. 5). Additionally, we find strong support for some of its constituent internal nodes, which indicate that neither Eriosorus nor Jamesonia sensu stricto is monophyletic. Phylogenetic analyses incorporating a more comprehensive sample of taxa and a greater number of markers will ultimately be necessary to fully understand evolutionary relationships within this clade. However, based solely on the evidence to date, it is abundantly clear that Jamesonia and Eriosorus (as typically circumscribed) cannot both be recognized, assuming monophyly as a criterion for generic delimitation. With Jamesonia being the older name (published in 1830, versus 1852 for Eriosorus), the recombination of all known species of Eriosorus into Jamesonia in Christenhusz et al. (2011) was mostly warranted.

Eriosorus myriophyllus was shown by Prado et al. (2007), Sánchez-Baracaldo (2004b), and Schneider et al. (2013) to be isolated relative to most other species previously assigned to Eriosorus or Jamesonia sensu stricto. Here, we find E. myriophyllus and two previously unsampled species of Eriosorus to be more closely related to Austrogramme, Pterozonium, Syngramma, and Taenitis than to Jamesonia (as newly circumscribed herein, Fig. 5). Support for this relationship is strong $(B P P=1.00)$ and the implications are significant if monophyly is used as a criterion for generic delimitation. Because the type of Jamesonia (Jamesonia pulchra Hook. \& Grev.) is resolved well within the large Jamesonia clade and the type of Eriosorus (E. aureonitens (Hook.) Copel.) shows clear morphological and geographical affinities to this clade, and because there are no other generic names available for the E. myriophyllus group, we here describe a new genus - Tryonia (see below) — to accommodate the isolated species.

In her monograph of Eriosorus, Tryon (1970) identified several small groups of closely allied species. Among these was the species pair of E. myriophyllus and E. sellowianus (with E. schwackeanus considered by her to be a synonym of E. sellowianus). This group corresponds perfectly to our proposed circumscription of Tryonia. We find $E$. myriophyllus, E. schwackeanus (which we consider to be distinct from E. sellowianus), and the recently described E. areniticola (Schwartsburd and Labiak 2008) to form a genetically isolated clade of closely related species (Fig. 5). New combinations for these species, along with the unsampled E. sellowianus, are provided below.

Based on our current dataset, we do not consider the precise phylogenetic position of Tryonia (within the Austrogramme, Pterozonium, Syngramma, Taenitis, and Tryonia clade) to be fully resolved. Although our combined analysis clearly places Tryonia sister to Austrogramme, Syngramma, and Taenitis (collectively), this relationship is not well supported in any single-gene analysis. The atp $A$ and $r b c L$ datasets do place Tryonia sister to Taenitis (atpA and $r b c L$ sequences were not available for Austrogramme and Syngramma), but support is lacking (BPP $=0.61$ and 0.83 , respectively). Likewise, the rps4 dataset resolves Tryonia as sister to Austrogramme, Syngramma, and Taenitis without significant support $(\mathrm{BPP}=0.88)$. Strong single-gene support for the precise 
position of Tryonia only comes from the chlL dataset, where Tryonia is most closely related to Pterozonium $(\mathrm{BPP}=1.00)$.

Two of the species of Tryonia included in our phylogenetic analysis (T. areniticola and T. schwackeana) are endemic to Brazil; the third sampled species (T. myriophylla) also occurs in Uruguay, near its border with the Brazilian state of Rio Grande do Sul. Although the Andes are the center of diversity for Jamesonia (as newly circumscribed herein), this genus is not entirely geographically distinct from Tryonia. In the recently published Catálogo de Plantas e Fungos do Brasil, a total of nine species are ascribed to Eriosorus or Jamesonia (Prado 2010). Only three of these species noted for Brazil (E. areniticola, E. myriophyllus, and E. schwackeanus) are resolved as sister to Austrogramme, Syngramma, and Taenitis. We found Eriosorus cheilanthoides, E. insignis, and J. brasiliensis to be embedded within the Jamesonia clade (Fig. 5) and E. rufescens was resolved within Jamesonia in an earlier study (Sánchez-Baracaldo 2004b). As for the remaining Brazilian species that have yet to be included in a phylogenetic study, one (E. sellowianus) shows clear morphological affinities to, and is here considered to be a member of, Tryonia; the other (E. biardii) appears, based on morphology, to be best accommodated in Jamesonia. Regardless of the ultimate phylogenetic placement of these two unsampled species, the genus Tryonia can be described as wholly endemic to Brazil and Uruguay.

\section{Taxonomy}

Tryonia Schuettp., J.Prado \& A.T.Cochran, gen. nov.

urn:Isid:ipni.org:names:77136217-1

http://species-id.net/wiki/Tryonia

Figs 4, 6-9

Similar to some species of Jamesonia, but with stramineous rather than castaneous rachises.

Type. Tryonia myriophylla (Sw.) Schuettp., J.Prado \& A.T.Cochran, comb. nov., Gymnogramma myriophylla Sw., Kongl. Vetensk. Acad. Handl. 1817(1): 58. 1817.

Description. Plants terrestrial, rupicolous, or saxicolous. Rhizomes creeping to erect at apex, compact, with appressed hairs or crispate bristles, sometimes rigid, ruddy brown, darker at the base. Fronds erect, 6-100 cm long; petioles terete or sulcate adaxially, brown at base and stramineous distally, from $1 / 8$ as long to equal the length of the lamina, densely to sparsely pubescent, the hairs short and erect or long and crispate, hyaline or reddish brown at the cell junctions, glandular or non-glandular; laminae linear to elongate-triangular, 1 or 2-pinnate-pinnatissect to 1-3-pinnate-pinnatifid, 4.0-48 cm long, 1.0-14 cm wide, determinate; rachises straight, sometimes slightly flexuous, terete or sulcate adaxially, stramineous, pubescent, the hairs like those of the petioles; pinnae ascending to patent to the rachis, oblong to deltate, $0.5-10 \mathrm{~cm}$ long, $0.5-5 \mathrm{~cm}$ wide, membranaceous to herbaceous, densely to sparsely pubescent on both surfaces, the hairs glandular, hyaline or with the terminal cell light to dark red- 


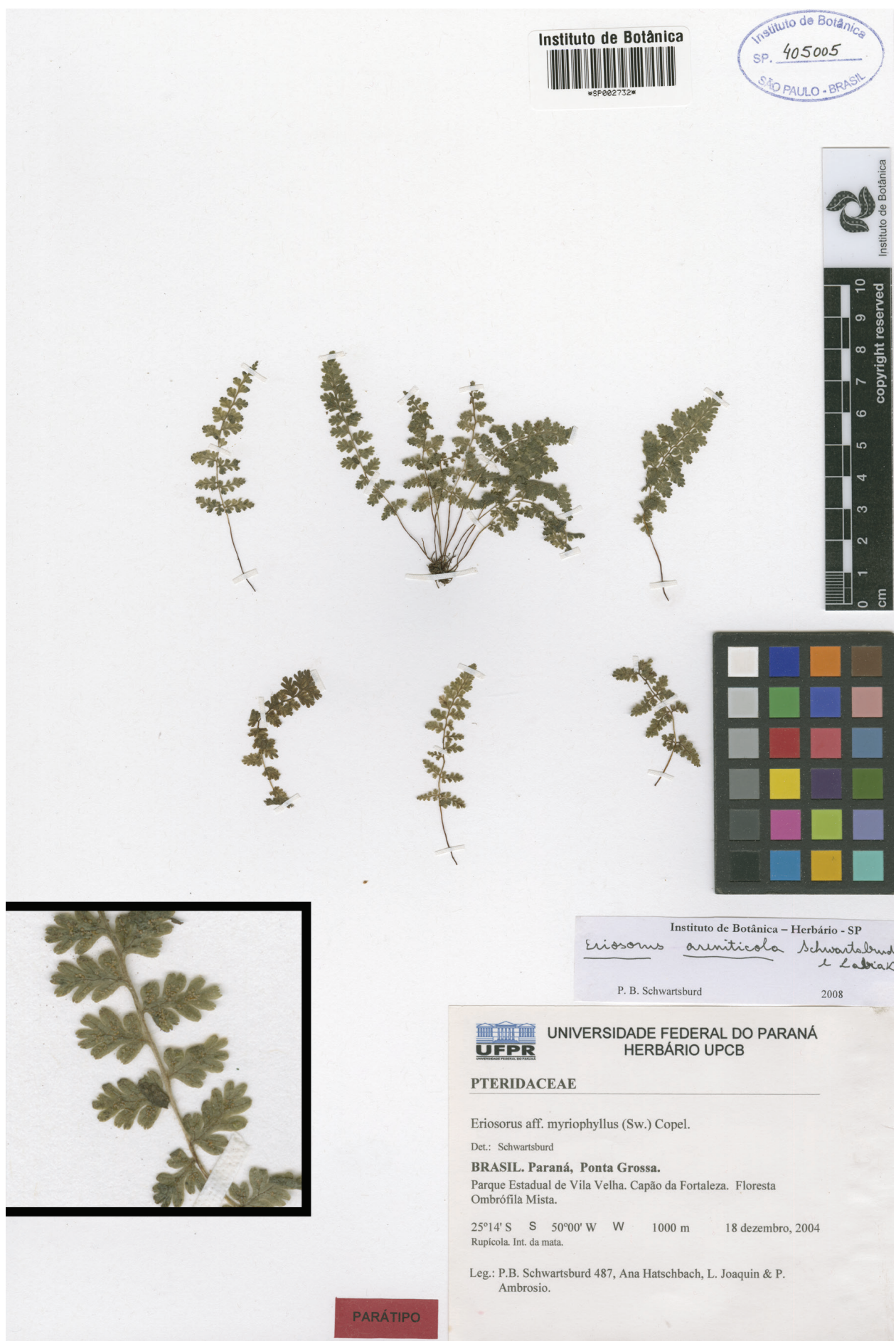

Figure 6. Tryonia areniticola (Schwartsb. \& Labiak) Schuettp., J.Prado \& A.T.Cochran. Schwartsburd 487 (SP), inset detail of (stramineous) rachis magnified $4 \times$. 
dish brown, 2-5-celled, or hairs non-glandular, hyaline or reddish brown at the cell junctions, 2-5(-7)-celled; ultimate segments entire and round or emarginate; veins free. Sporangia borne along the veins, short-stalked, stalks 1-2-celled, stomia with 2-4 indurated cells; spores trilete, tetrahedral-globose, with an equatorial flange, distal face coarsely tuberculate, proximal face with prominent ridges, brown, 40-60 $\mu \mathrm{m}$ (Fig. 9).

Etymology. The generic name honors Dr. Alice Faber Tryon, who made extraordinary contributions to fern systematics and published taxonomic revisions of both Jamesonia sensu stricto and Eriosorus (from which Tryonia is segregated herein).

Distribution. Tryonia occurs primarily in southeastern Brazil. However, one species (T. myriophylla) can also be found in Uruguay (Cerro Largo: Sierra Souza), near the Brazilian border. The genus is mostly restricted to the Atlantic Forest, along shaded streams, on damp shaded sandstone, or in more open places (but here shaded by shrubs); 600-2300 m.

Discussion. Tryonia can be distinguished most readily from Jamesonia by its stramineous rachises, but its gross morphology is also reasonably distinct. Tryon (1970) referred to the leaves of $T$. myriophylla as "generalized" (i.e., elongate-triangular and well developed). She drew a distinction between them and the "specialized" (i.e., either complex and scandent or compact and linear) leaves of Jamesonia sensu stricto and many other species at the time placed in Eriosorus, as well as between them and the "intermediate" (i.e., falling between the two extremes) leaves of other species she treated in Eriosorus. Although the Andean Jamesonia congesta also has "generalized" leaves, it is readily distinguished from Tryonia by its rachis color. The only species of Jamesonia with occasionally stramineous rachises (J. flexuosa) has "specialized" (complex and scandent) leaves. Spores of Tryonia (Fig. 9) and Jamesonia are basically indistinguishable.

Tryonia comprises the following species.

\section{Tryonia areniticola (Schwartsb. \& Labiak) Schuettp., J.Prado \& A.T.Cochran, comb. nov.}

urn:Isid:ipni.org:names:77136218-1

http://species-id.net/wiki/Tryonia_areniticola

Figs 6, 9

Synonym: Jamesonia areniticola (Schwartsb. \& Labiak) Christenh. (Phytotaxa 19: 20. 2011).

Basionym. Eriosorus areniticola Schwartsb. \& Labiak (Amer. Fern J. 98: 160. 2008).

Type. Brazil: Paraná: Jaguariaíva: Parque Estadual do Cerrado, 12 April 1994, P.H. Labiak 182 (holotype: UPCB; isotypes: SP!, UC).

Distribution. Brazil: Paraná, Rio Grande do Sul, Santa Catarina (probably), and São Paulo.

Discussion. Based on the gene regions included in our analysis, we found Tryonia areniticola to be genetically indistinguishable from $T$. myriophylla, despite the presence of several morphological differences (Schwartsburd and Labiak 2008). Further studies that include nuclear markers will be necessary. 

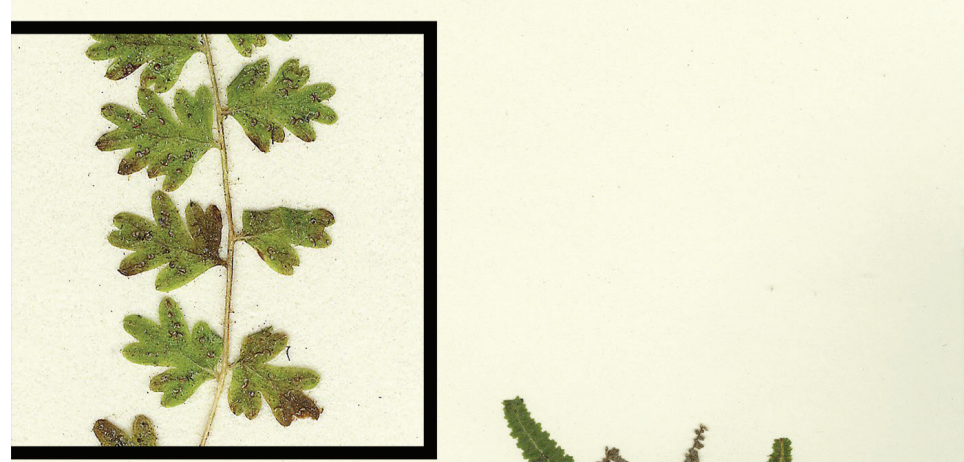

MISSOURI

BOTANICAL GARDEN

HERBARIUM

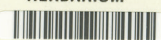

№ 6209211
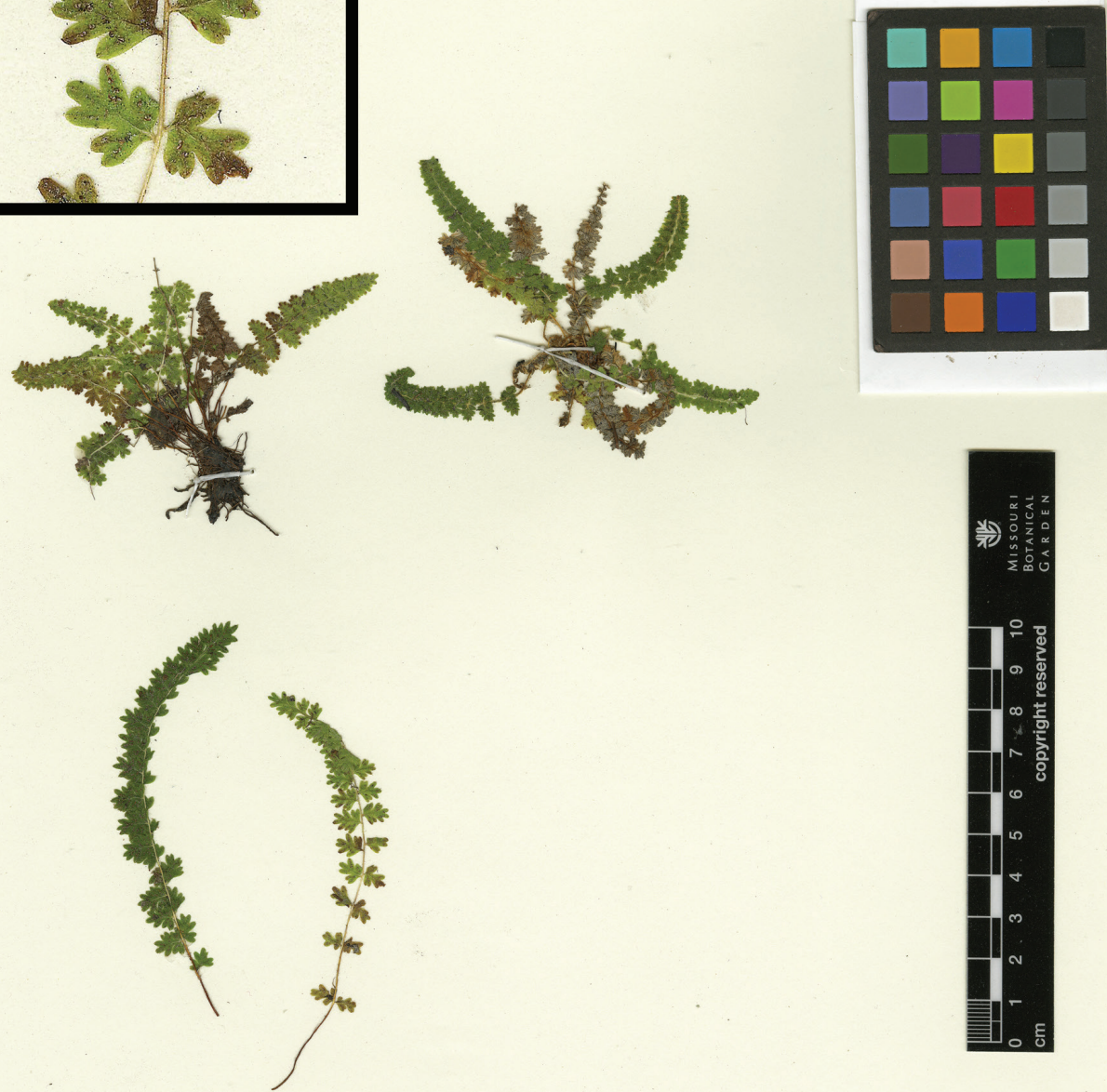

FERNS OF BRAZIL

PTERIDACEAE

Eriosorus cheilanthoides (Sw.) A.F. Tryon

Brazil: Minas Gerais: Santana do Riacho: Serra do Espinhaço: between Conceição do Mato Dentro and Lagoa Santa, off MG-010, in Serra do Cipó National Park at crossing of Rio Três Pontinhas.

$-19.26557 ;-43.54358 ; 1320 \mathrm{~m}$.

Campos Rupestres: in sandstone crevice left of waterfall system (SW exposure) Fronds somewhat viscid. Scattered. With mosses and Selaginella.

E Schuettpelz 1433 (with J Prado, PB Schwartsburd, and G Yatskievych) 17 Jan 2010

Three specimens collected, deposited at SP, MO, and DUKE. Additional material silica-dried for DNA

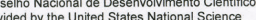
Tecnológico (permit 010239/2009-0). Funding provide
Foundation (grants DEB-0717398 and DEB-0717430)

Figure 7. Tryonia schwackeana (Christ) Schuettp., J.Prado \& A.T.Cochran. Schuettpelz 1433 (MO), inset detail of (stramineous) rachis magnified $4 \times$. Image modified from http://www.tropicos.org/Image/100140486. 


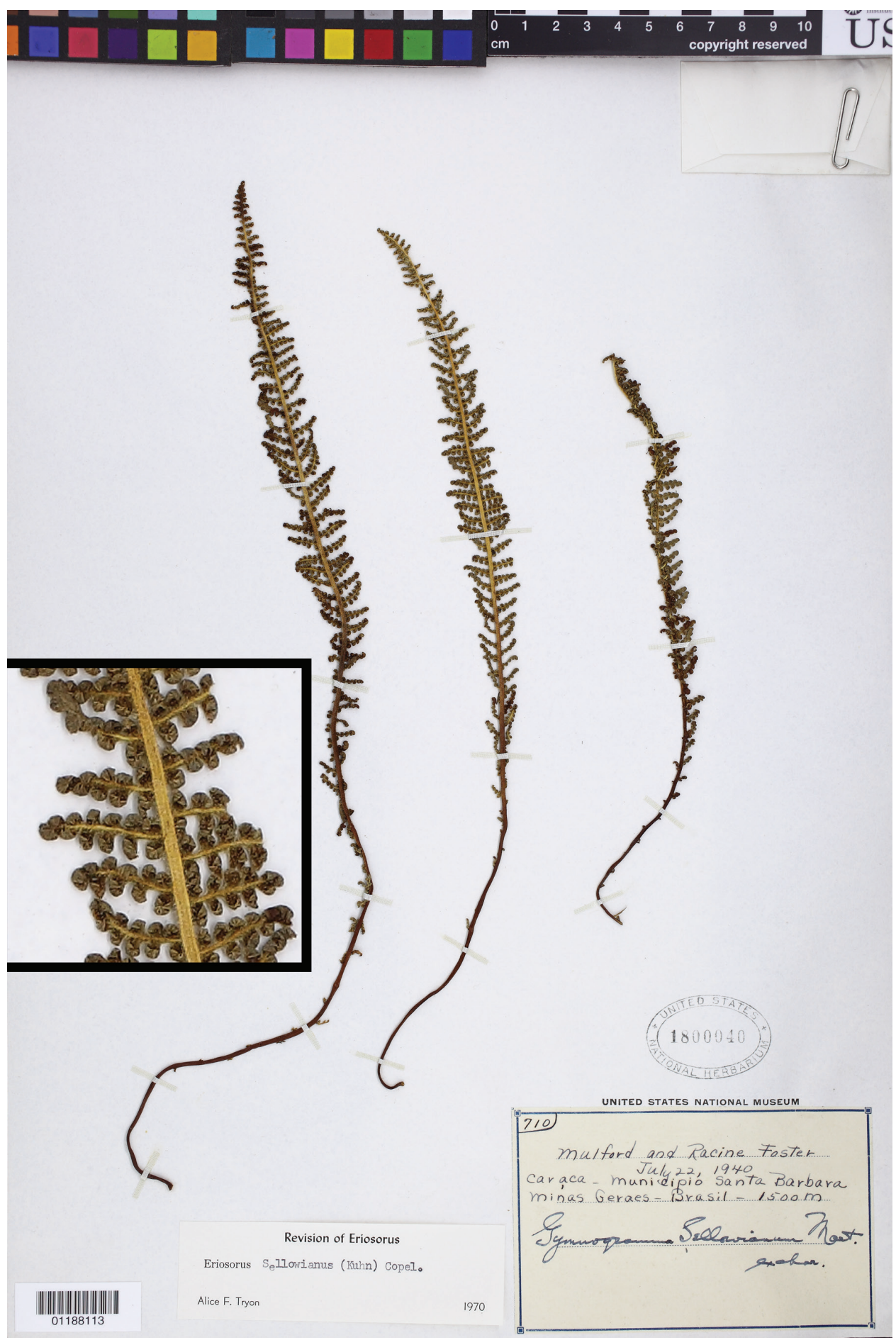

Figure 8. Tryonia sellowiana (Kuhn) Schuettp., J.Prado \& A.T.Cochran. Mulford 710 (US), inset detail of (stramineous) rachis magnified $4 \times$. 
Tryonia myriophylla (Sw.) Schuettp., J.Prado \& A.T.Cochran, comb. nov. urn:Isid:ipni.org:names:77136219-1

http://species-id.net/wiki/Tryonia_myriophylla

Figs 4, 9

Synonyms: Psilogramme myriophylla (Sw.) Kuhn (Festschr. 50 Jähr. Jub. Königstädt. Realschule Berlin 339. 1882); Eriosorus myriophyllus (Sw.) Copel. (Gen. Fil. 58. 1947); Jamesonia myriophylla (Sw.) Christenh. (Phytotaxa 19: 21. 2011).

Basionym. Gymnogramma myriophylla Sw. (Kongl. Vetensk. Acad. Handl. 1817(1): 58. 1817).

Type. Brazil: [Minas Gerais]: Villa Rica [now Ouro Preto], Aug 1815, G. W. Freyriss s.n. (lectotype [designated by Tryon, 1970]: S-R-2467, image!; isolectotypes: BM 000936677, image!, S-R-2469, image!).

Distribution. Brazil: Bahia, Espírito Santo, Minas Gerais, Paraná, Rio de Janeiro, Santa Catarina, Sáo Paulo, and Rio Grande do Sul. Uruguay: Cerro Largo.

Tryonia schwackeana (Christ) Schuettp., J.Prado \& A.T.Cochran, comb. nov. urn:Isid:ipni.org:names:77136220-1

http://species-id.net/wiki/Tryonia_schwackeana

Fig. 7

Synonym: Eriosorus schwackeanus (Christ) Copel. (Gen. Fil. 59. 1947).

Basionym. Gymnogramma schwackeana Christ in Schwacke (Pl. Nov. Mineiras 2.18. 1900).

Type. Brazil: [Minas Gerais]: Ouro Preto, C.A.W. Schwacke 9389 (lectotype [designated by Tryon, 1970]: P 00603566, image!; isolectotype: GH 00021287, image!).

Distribution. Brazil: Bahia and Minas Gerais.

Tryonia sellowiana (Kuhn) Schuettp., J.Prado \& A.T.Cochran, comb. nov. urn:Isid:ipni.org:names:77136221-1

http://species-id.net/wiki/Tryonia_sellowiana

Fig. 8

Synonyms: Psilogramme sellowiana (Mett. ex Kuhn) Kuhn (Festschr. 50 Jähr. Jub. Königstädt. Realschule Berlin 339. 1882); Eriosorus sellowianus (Mett. ex Kuhn) Copel. (Gen. Fil. 59. 1947); Jamesonia sellowiana (Mett. ex Kuhn) Christenh. (Phytotaxa 19: 21. 2011). 
Basionym. Gymnogramma sellowiana Mett. ex Kuhn (Linnaea 36:69. 1869).

Type. Brazil, Sello 1365 (lectotype [designated by Tryon, 1970]: B-Herb. Mett., image!; isolectotype: $\mathrm{B}$, image!)

Distribution. Brazil: Minas Gerais.
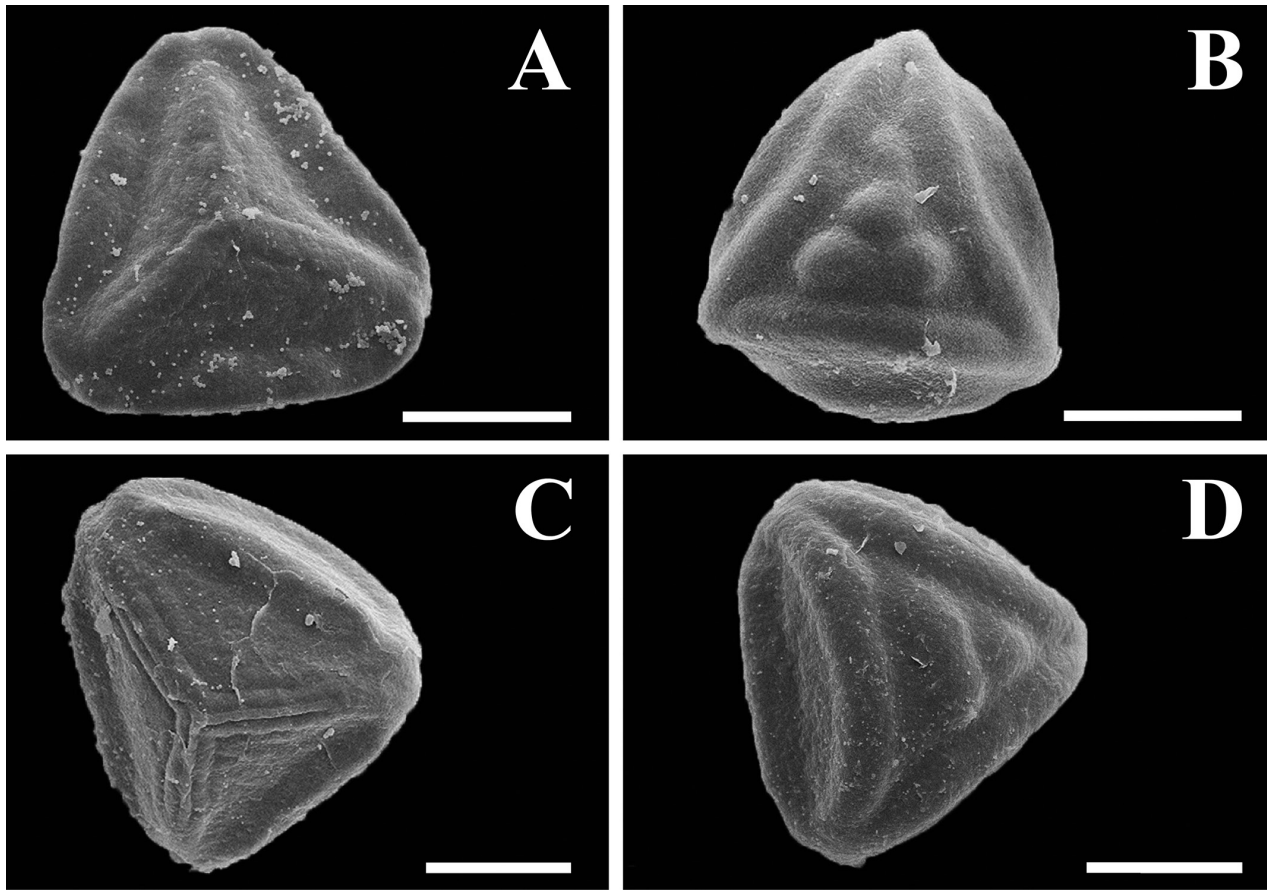

Figure 9. Spores of Tryonia. A. Tryonia myriophylla proximal view, Wacket s.n. (US) B Tryonia myriophylla distal view, Wacket s.n. (US) C Tryonia areniticola proximal view, Kummrow 2773 (US) D Tryonia areniticola distal view, Kummrow 2773 (US). All scale bars are $20 \mu \mathrm{m}$.

\section{Acknowledgements}

This research was funded in part by the National Science Foundation (NSF awards DEB-0717398, DEB-0717430, DEB-1145614, and DEB-1145925), the Conselho Nacional de Desenvolvimento Científico e Tecnológico (CNPq award 301157/20103), and a Cahill Award from the University of North Carolina Wilmington. Amanda Grusz, Anders Larsson, Robbin Moran, Carl Rothfels, Harald Schneider, Alan Smith, Michael Sundue, and George Yatskievych provided material or assisted in material acquisition. Alex Davila, Patricia Kelley, Jerald Pinson, Ann Stapleton, Marcel van Tuinen, and three reviewers provided helpful comments on the manuscript. Specimen images were provided by the Missouri Botanical Garden and by Ingrid Lin of the Smithsonian Institution. Scott Whittaker assisted with spore imaging and Regina Hirai prepared the spore plate. 


\section{References}

Beck JB, Alexander PJ, Allphin L, Al-Shehbaz IA, Rushworth C, Bailey CD, Windham MD (2011) Does hybridization drive the transition to asexuality in diploid Boechera? Evolution 66: 985-995. doi: 10.1111/j.1558-5646.2011.01507.x

Christenhusz M, Zhang X, Schneider H (2011) A linear sequence of extant families and genera of lycophytes and ferns. Phytotaxa 19: 7-54.

Doyle JJ, Doyle JL (1987) A rapid DNA isolation procedure for small quantities of fresh leaf tissue. Phytochemical Bulletin 19: 11-15.

Huelsenbeck JP, Ronquist F (2001) MRBAYES: Bayesian inference of phylogeny. Bioinformatics 17: 754-755. doi: 10.1093/bioinformatics/17.8.754

Maddison WP, Maddison DR (2011) Mesquite: A Modular System for Evolutionary Analysis. Version 2.75. http://mesquiteproject.org

Prado J, Rodrigues CDN, Salatino A, Salatino MLF (2007) Phylogenetic relationships among Pteridaceae, including Brazilian species, inferred from $r b c L$ sequences. Taxon 56: 355-368.

Prado J (2010) Pteridaceae. In: Forzza RC, Baumgratz JFA, Bicudo CEM, Carvalho Jr. AA, Costa A, Costa DP, Hopkins M, Leitman PM, Lohmann LG, Maia LC, Martinelli G, Menezes M, Morim MP, Coelho MAN, Peixoto AL, Pirani JR, Prado J, Queiroz LP, Souza VC, Stehmann JR, Sylvestre LS, Walter BMT, Zappi D (Eds) Catálogo de Plantas e Fungos do Brasil, Volume 1. Jardim Botânico do Rio de Janeiro, Rio de Janeiro, 552-559.

Rambaut A, Drummond AJ (2009) Tracer. Version 1.5. http://tree.bio.ed.ac.uk/software/tracer

Ronquist F, Huelsenbeck JP (2003) MRBAYES 3: Bayesian phylogenetic inference under mixed models. Bioinformatics 19: 1572-1574. doi: 10.1093/bioinformatics/btg180

Sanchez-Baracaldo P (2004a) Phylogenetic relationships of the subfamily Taenitidoideae, Pteridaceae. American Fern Journal 94: 126-142. doi: 10.1640/0002-8444(2004)094[0126:PR OTST]2.0.CO;2

Sanchez-Baracaldo P (2004b) Phylogenetics and biogeography of the neotropical fern genera Jamesonia and Eriosorus (Pteridaceae). American Journal of Botany 91: 274-284. doi: 10.3732/ajb.91.2.274

Schneider H, He L, Hennequin S, Zhang X-C (2013) Towards a natural classification of Pteridaceae: inferring the relationships of enigmatic pteridoid fern species occurring in the SinoHimalaya and Afro-Madagascar. Phytotaxa 77: 49-60. doi: 10.11646/phytotaxa.77.4.1

Schuettpelz E, Pryer KM (2007) Fern phylogeny inferred from 400 leptosporangiate species and three plastid genes. Taxon 56: 1037-1050. doi: 10.2307/25065903

Schuettpelz E, Schneider H, Huiet L, Windham MD, Pryer KM (2007) A molecular phylogeny of the fern family Pteridaceae: Assessing overall relationships and the affinities of previously unsampled genera. Molecular Phylogenetics and Evolution 44: 1172-1185. doi: 10.1016/j.ympev.2007.04.011

Schwartsburd PB, Labiak PH (2008) Eriosorus areniticola (Pteridaceae), a new species from Brazil. American Fern Journal 98: 160-163. doi: 10.1640/0002-8444(2008)98[160:EAPANS]2.0.CO;2 
Souza-Chies TT, Bittar G, Nadot S, Carter L, Besin E, Lejeune B (1997) Phylogenetic analysis of Iridaceae with parsimony and distance methods using the plastid gene rps4. Plant Systematics and Evolution 204: 109-123. doi: 10.1007/BF00982535

Tryon AF (1962) A monograph of the fern genus Jamesonia. Contributions from the Gray Herbarium of Harvard University 191: 109-197.

Tryon AF (1970) A monograph of the fern genus Eriosorus. Contributions from the Gray Herbarium of Harvard University 200: 54-174.

Tryon RM, Tryon AF (1982) Ferns and Allied Plants with Special Reference to Tropical America. Springer-Verlag. doi: 10.1007/978-1-4613-8162-4

Tryon RM, Tryon AF, Kramer KU (1990) Pteridaceae. In: Kramer KU, Green PS (Eds) The Families and Genera of Vascular Plants, Volume 1, Pteridophytes and Gymnosperms. Springer-Verlag, 230-256. 